удК 338.486

\title{
АНАЛІЗ РЕСУРСНОГО ПОТЕНЦІАЛУ УКРАЇНИ ЩОДО ОРГАНІЗАЦІї ТА РЕАЛІЗАЦІї МІЖНАРОДНИХ КРУЇЗІВ
}

\section{ANALYSIS OF THE RESOURCE POTENTIAL OF UKRAINE REGARDING THE ORGANIZATION AND REALIZATION OF INTERNATIONAL CRUISES}

\author{
Романова Анна Анатоліївна \\ доктор економічних наук, доцент, \\ Київський національний економічний університет \\ імені Вадима Гетьмана \\ ORCID: https://orcid.org/0000-0001-7336-1032 \\ Бицань Євгеній Олексійович \\ студент, \\ Київський національний економічний університет \\ імені Вадима Гетьмана \\ ORCID: https://orcid.org/0000-0002-6295-0365
}

\author{
Romanova Anna, Bytsan Yevhenii \\ Kyiv National Economic University named after Vadym Hetman
}

\begin{abstract}
Для визначення ресурсного потенціалу України щодо організації та обслуговування круїзних напрямків було досліджено інсрраструктурні та туристичні наявні ресурси, які $є$ обов'язковою умовою та складовою круїзного маршруту: глибоководні річки; портові термінали, які призначені для обслуговування пасажирів; туристичні підприємства, які займаються організацією круїзів; дестинації другого плану (місця з туристичним потенціалом, які приваблюють туристів та знаходяться в зоні доступності круїзних лайнерів). Проведено аналіз вже задіяних ресурсів та тих, які можуть використовуватися без попередньої підготовки для організації круїзних подорожей. Досліджено круїзні ресурси, які нині не використовуються для організації круїзних подорожей та обслуговування. Сфрормульовано рекомендації для відновлення та розвитку міжнародної круїзної індустрії в Україні.
\end{abstract}

Ключові слова: круїзний туризм; туристична індустрія; туристична дестинація, портові термінали, туристичні атракції.

Для определения ресурсного потенциала Украины в организации та обслуживании круизных направлений было исследовано инфраструктуру и имеющиеся туристические ресурсы, которые являются обязательным условием и частью круизного маршрута: полноводные реки, портовые терминалы, которые предназначены для обслуживания пассажиров; туристические предприятия, которые занимаются организацией круизов; дестинации второго плана (места с туристическим потенциалом, которые привлекают туристов и находятся в зоне доступности круизных лайнеров). Был проведен анализ уже задействованных ресурсов, а также тех, которые могут быть использованы без предыдущей подготовки для организации круизных путешествий. Также проведен анализ тех ресурсов, которые не используются для организации круизных путешествий и обслуживания. Были сфрормулированы рекомендации для восстановления и развития международной круизной индустрии в Украине.

Ключевые слова: круизный туризм, туристическая индустрия, туристическая дестинация, портовые терминалы, туристские аттракции.

In this work a revelation of resource potential of Ukraine in organizing and maintenance of cruise directions was made. Cruises within the country and in the international format are an important part of the tourist potential of any country and are in great demand among tourist. After stagnation due to the COVID-19 pandemic, cruise companies are expected to have the same number of tourists taking the journeys as before the pandemic or even more. 
This aspect can be used by country to attract more material goods during the tourist seasons and also strengthen the position of the country on the international level. Due to these reasons the infrastructure and available tourist resources in Ukraine were studied, which are an essential condition and part of the cruise route: deep rivers port terminals which are designed to serve passengers; travel companies that organize cruises; second plan destinations (places with tourist potential which attract tourists and are within the reach of cruise ships). An analysis was made of the resources that are already involved, as well as those that can be used without previous preparation for organizing cruise journey. Also, the analysis was made about those resources, that are not involved in organization of cruise journeys and their service. Recommendations were formulated for the restoration and development of the international cruise industry in Ukraine. Problems with port terminals availability, infrastructure as well as other tourist attractions are stated to be an essential issue regarding a quantity of tourists taking the cruises each year in Ukraine as well as a quality of the services they are provided with. Potential that Ukraine has in terms of natural resources and tourist attractions is not used in sufficient quantities to serve the interests of more tourists. Also indicated an insufficient number of companies that are engaged in cruise tourism in Ukraine. By analyzing these issues in the context of the international cruise industry, opportunities can be found for its further development and improvement in number of cruise journeys in Ukraine as well as improvement tourist industry in the country in general.

Keywords: cruise tourism, travel industry, travel destination, port terminals, tourist's attraction.

Постановка проблеми. Після початку пандемії COVID-19 вся світова круїзна галузь перейшла у тривалу фразу стагнації [1]. Що стосується сучасної української круїзної індустрії, то галузь вже давно перебуває у стані кризи, а зараз опинилася на одному рівні зі світовою, що створює рівні можливості для її подальшого відновлення та розвитку у контексті міжнародної круїзної індустрії.

Аналіз джерел та публікацій демонструє високий рівень обізнаності вітчизняних та іноземних науковців щодо рівня впливу та важливості круїзної індустрії на міжнародну туристичну галузь. Дослідженням на тему круїзної галузі присвятили свої роботи багато вітчизняних науковців серед них варто виокремити: І. Антоненко, О. Аріон, В. Герасименко, Н. Добрянська, Н. Логунова, І. Мельник, Н. Опанасюк, С. Нездомінов, С. Шпилько.

Виділення невирішених раніше частин загальної проблеми. Відсутність, будь-якої, стратегії розвитку української круїзної галузі в контексті міжнародної туристичної індустрії.

Ціль статті: розкриття ресурсного потенціалу України щодо організації та реалізації міжнародних круїзів. У контексті мети у дослідженні було реалізовано наступні завдання:

- проаналізовано водні ресурси України для організації міжнародних круїзів;

- проаналізовано туристичні ресурси України для створення попиту на міжнародні круїзи;

- сорормульовано висновки та рекомендації для відновлення і розвитку сектору міжнародної круїзної індустрії України.

Виклад основного матеріалу дослідження. Станом на початок 2014 року і Україні фрункціонували дві туристичні компанії, котрі займалися організацією круїзних турів: Акціонерне товариство «Українське дунайське пароплавство» (м. Ізмаїл) та Товариство 3 обмеженою відповідальністю «Круїзна компанія «Червона рута»». Ці дві компанії займалися переважно організацією внутрішніх річкових круїзних турів. Станом на сьогодні 3 5 суден, які експлуатувалися ТОВ «Круїзна компанія «Червона рута»», нині використовуються тільки два: «Принцеса Дніпра» на 154 номери та прогулянковий пароплав «Rosa Victoria» [2].

Також варто зауважити, що українські туристи складають приблизно 5\% від всіх пасажирів круїзних турів, які здійснюються вищезгаданими компаніями. Решта 95\% складають резиденти із 41 країни світу.

Зазначимо, що окрім двох компаній, які $€$ круїзними туристичними операторами, в Україні фрункціонує агентство з продажу круїзних турів компанії «MSC Cruises». Інших туристичних підприємств, які займаються організацією чи продажем круїзних турів, маршрут яких починається та/або проходить через українські водні території не виявлено.

Тож, після аналізу круїзних туристичних підприємств, які функціонують в Україні, слід зробити висновок, що подібна галузь туристичної індустрії $\epsilon$ слаборозвиненою, що призводить до відсутності релевантних пропозицій круїзних турів на українському ринку.

Перейдемо до аналізу водних ресурсів України, які використовуються як суднопроводи для круїзних лайнерів. Пропонується розпочати аналіз з характеристики найбільших українських річок, які задіяні при організації круїзів. Серед всіх глибоководних річок станом на сьогодні тільки дві використовуються як суднопроводи при реалізації круїзів:

1. Дунай - міжнародна водна артерія, яка протікає через 17 країн європейського континенту. На жаль, вітчизняні круїзні компанії реалізують виключно внутрішні круїзні тури (по україн- 
ській акваторії Дунаю), ігноруючи весь круїзний ресурсний потенціал цього водного об'єкту.

2. Дніпро - найбільша річка України, яка протікає територією західної Росії (Смоленська область) та південно-східною територією Білорусі. Проте, переважна більшість довжини Дніпра проходить саме через українську територію, після чого вона впадає в українську акваторію Чорного моря. На жаль, як і в ситуації з Дунаєм, вітчизняні круїзні компанії реалізують виключно внутрішні круїзні тури (по українській акваторії Дніпра), ігноруючи весь круїзний ресурсний потенціал цього водного об'єкту.

Розглянемо українські водні шляхи, що придатні для організації круїзів, проте поки не використовуються за даним призначенням. До таких річок слід віднести Дністер, яка бере початок на Львівщині і проходить територією Прикарпаття, Буковини та Бессарабії (частково через територію Молдови) й впадає у Чорне море. Тож ця річка може використовуватися для організації міжнародних круїзів, маршрут яких пролягатиме через Україну, Молдову та виходитиме до акваторії Чорного моря.

ще однією рікою, з якої можуть починатися українські круїзні маршрути, є Південний Буг. Достатня глибина цього водного об'єкту дозволить туристам ознайомитися 3 центральною та південною Україною після чого лайнер може вийти в Чорне море та продовжити свій рейс, відвідуючи іноземні порти.

Тож, після аналізу річкових водних об'єктів України, варто зазначити, що тільки дві річки використовуються для круїзних турів (Дніпро та Дунай). Проте, навіть ці водні шляхи не використовуються повною мірою, потенціал організації міжнародних круїзів поки не реалізований вітчизняними круїзними туристичними операторами. Щодо інших великих річок та притоків вже задіяних, то незважаючи на весь їхній ресурсний потенціал, який може використовуватися для організації внутрішніх та міжнародних круїзних рейсів, вони ігноруються українськими круїзними туроператорами.

Для повноцінного аналізу українських водних об'єктів, які можуть бути задіяні при реалізації та розробці круїзних маршрутів, слід розглянути ще два найбільших водних об'єктів України - Чорне та Азовське моря.

Акваторія Азовського моря поки ніяк не використовується для організації круїзних рейсів. Цим українські круїзні компанії ігнорують великий потенціал даного водного об'єкту. Адже акваторія Азовського моря може використовуватися для внутрішніх та міжнародних круїзних рейсів. Також Азовське море може бути використане як стартова точка для великих круїзних маршрутів, які не обмежуватимуться акваторією цього водного об'єкту. Таким чином, круїзний лайнер може розпочати свій маршрут в одному з українських портів Приазов'я, після чого, вздовж азовського узбережжя Криму, пройти через Керченську протоку та опинитися у Чорному морі, що дозволяє прокласти круїзний маршрут через всі країни, які $€$ частиною Чорноморської акваторії.

Тож, використання всього круїзного потенціалу Азовського моря, призведе до зростання туристичних потоків, спрямованих до українських курортів Приазов'я, після відпочинку на яких, іноземні та внутрішні туристи зможуть вирушити у внутрішній чи міжнародний круїзний рейс.

Перейдемо до аналізу найбільшого водного об'єкту України, потенціал якого частково використовується для організації круїзних подорожей - Чорного моря. До 2014 року деякі міжнародні круїзні маршрути починалися або включали до себе Чорноморські українські порти, що розташовані в Криму. Після анексії українського Криму Російською Федерацією, дані круїзні маршрути були змінені чи заморожені. Нині єдиним українським портовим містом, з якого починаються чи заходять міжнародні круїзні рейси, є Одеса. Дочірнє туристичне агентство міжнародної круїзної компанії «MSC Cruises» пропонує на українському та східноєвропейському круїзних ринках тури по маршрутах, які починаються з цього міста.

Тож, після аналізу круїзної діяльності в акваторії Чорного моря, слід зробити наступний висновок: після втрати контролю над українськими морськими портами в Криму, залишився тільки один порт (Одеса), з якого починаються всі круїзні маршрути, інші потенційні ресурси не використовуються.

Після того, як був проведений аналіз та надана характеристика всім водним ресурсам України, що можуть бути використані та вже задіяні для круїзних подорожей, необхідно перейти до аналізу круїзного ресурсного потенціалу українських портів.

Для повноти проведеного аналізу ресурсного потенціалу України щодо організації морських та річкових круїзних маршрутів слід проаналізувати ще одну складову, яка $є$ критично необхідною для круїзних подорожей, а саме: наявність наземних туристичних дестинацій, які можуть зацікавити пасажирів та до яких можуть заходити круїзні лайнери. 
Таблиця 1

Характеристика українських портів, які використовуються та мають потенціал для організації круїзів

\begin{tabular}{|c|c|c|c|c|}
\hline № & Назва & К-ть терміналів, од. & $\begin{array}{c}\text { Пропускна } \\
\text { спроможність } \\
\text { пасажирів, ос. }\end{array}$ & Статус \\
\hline 1. & $\begin{array}{c}\text { Білгород- } \\
\text { Дністровський }\end{array}$ & 4 & 0 & $\begin{array}{c}\text { Непридатний, } \\
\text { не використовується }\end{array}$ \\
\hline 2. & Бердянський & 6 & 0 & $\begin{array}{c}\text { Непридатний, } \\
\text { не використовується }\end{array}$ \\
\hline 3. & Ізмаїльський & 3 & 152500 & $\begin{array}{c}\text { Придатний, } \\
\text { не використовується }\end{array}$ \\
\hline 4. & Маріупольський & 1 & 0 & $\begin{array}{c}\text { Непридатний, } \\
\text { не використовується }\end{array}$ \\
\hline 5. & Миколаївський & 18 & 0 & $\begin{array}{c}\text { Непридатний, } \\
\text { не використовується }\end{array}$ \\
\hline 6. & Одеський & 17 & 4000000 & $\begin{array}{c}\text { Придатний, } \\
\text { використовується }\end{array}$ \\
\hline 7. & СМП «Ольвія» & 1 & 0 & $\begin{array}{c}\text { Непридатний, } \\
\text { не використовується }\end{array}$ \\
\hline 8. & Південний & 15 & 0 & $\begin{array}{c}\text { Непридатний, } \\
\text { не використовується }\end{array}$ \\
\hline 9. & Ренійський & 11 & 5000 & $\begin{array}{c}\text { Придатний, } \\
\text { не використовується }\end{array}$ \\
\hline 10. & Скадовський & 2 & 0 & $\begin{array}{c}\text { Непридатний, } \\
\text { не використовується }\end{array}$ \\
\hline 11. & Усть-Дунайський & 3 & 10000 & $\begin{array}{c}\text { Придатний, } \\
\text { не використовується }\end{array}$ \\
\hline 12. & Херсонський & 8 & 0 & $\begin{array}{c}\text { Непридатний, } \\
\text { не використовується }\end{array}$ \\
\hline 13. & Чорноморський & 12 & 25000 & $\begin{array}{c}\text { Придатний, } \\
\text { не використовується }\end{array}$ \\
\hline 14. & Севастопольський & $\begin{array}{l}\text { Інформація } \\
\text { недоступна }\end{array}$ & $\begin{array}{l}\text { Інорормація } \\
\text { недоступна }\end{array}$ & Тимчасово непридатні \\
\hline 15. & Євпаторійський & $\begin{array}{l}\text { Інорормація } \\
\text { недоступна }\end{array}$ & $\begin{array}{l}\text { Інорормація } \\
\text { недоступна }\end{array}$ & Тимчасово непридатні \\
\hline 16. & Феодосійський & $\begin{array}{l}\text { Інорормація } \\
\text { недоступна }\end{array}$ & $\begin{array}{l}\text { Інорормація } \\
\text { недоступна }\end{array}$ & Тимчасово непридатні \\
\hline 17. & Ялтинський & $\begin{array}{l}\text { Інорормація } \\
\text { недоступна }\end{array}$ & $\begin{array}{l}\text { Інорормація } \\
\text { недоступна }\end{array}$ & Тимчасово непридатні \\
\hline 18. & $\begin{array}{l}\text { Київський річковий } \\
\text { вокзал }\end{array}$ & 0 & - & $\begin{array}{c}\text { Придатний, } \\
\text { використовується }\end{array}$ \\
\hline
\end{tabular}

Джерело: складено авторами на основі [3]

Для ефрективного аналізу були виокремлені наступні параметри, за якими відбирались дестинації для подальшого розгляду (див. табл. 2):

- логістична доступність для пасажирів круїзного судна;

- туристична привабливість;

- туристичні ресурси, які можуть бути цінними для туристів лайнеру;

- наявність об'єктів ресторанного господарства, які можуть задовольнити потреби пасажирів під час їхнього сходження на берег;
- орієнтовна вартість споживання туристичних послуг, які пропонуються туристичними підприємствами наземної дестинації.

Результати та обговорення. Виходячи 3 даного дослідження, ссрормулюємо висновки про водний та туристичний ресурсний потенціал України для організації міжнародних круїзів: на території України є всього два порти, які використовуються для організації круїзних рейсів, ще п'ять портів, які вже зараз можуть використовуватись для організації круїзних подорожей, адже вони мають пасажирські 
Таблиця 2

Характеристика наземних круїзних дестинацій України

\begin{tabular}{|c|c|c|c|c|}
\hline № & Дестинація & Атракції & $\begin{array}{c}\text { Об. рест. } \\
\text { госп., од. }\end{array}$ & $\begin{array}{c}\text { Орієнтовна вартість } \\
\text { туристичних послуг, } \\
\text { грн. }\end{array}$ \\
\hline 1 & Одеса & $\begin{array}{c}\text { Пляж «Аркадія», клуб «Ібіца», } \\
\text { вулиця Дерибасівська Аквапарк, } \\
\text { мережа підземних тунелів }\end{array}$ & 1502 & $1000-1500$ \\
\hline 2 & Київ & $\begin{array}{c}\text { Києво-Печерська лавра, } \\
\text { історичний центр міста, 3оопарк, } \\
\text { парк атракціонів, торгівельно- } \\
\text { розважальні центри }\end{array}$ & 14700 & $1500-2500$ \\
\hline 3 & Прип'ять & $\begin{array}{c}\text { місто-привид - Прип'ять, } \\
\text { четвертий реактор ЧАЕС, } \\
\text { радіолокаційна станція «Дуга» }\end{array}$ & 27 & $500-1000$ \\
\hline 4 & Херсон & Олешківські піски, Асканія-Нова & 133 & $300-400$ \\
\hline 5 & Запоріжжя & О. Мала Хортиця & 189 & $250-350$ \\
\hline 6 & Черкаси & $\begin{array}{c}\text { Моринці, Чигирин, Черкаський } \\
\text { краєзнавчий музей, Набережна міста }\end{array}$ & 83 & $500-1000$ \\
\hline 7 & $\begin{array}{c}\text { Білгород- } \\
\text { Дністровський }\end{array}$ & $\begin{array}{c}\text { Фортифрікаційні споруди, } \\
\text { старовинні церкви }\end{array}$ & 20 & $300-400$ \\
\hline
\end{tabular}

Джерело: складено авторами на основі [4; 5]

термінали. Звернемо увагу на те, що на території України є ще 12 портів які в майбутньому потенційно можуть бути обладнанні та використовуватись для організації морських чи річкових круїзних рейсів. Проте варто зазначити, що п'ять із них знаходяться на території тимчасово окупованого українського Криму.

Також варто сорормувати твердження про те, що в Україні існує достатня кількість наземних дестинацій, які можуть приваблювати та обслуговувати пасажирів круїзних лайнерів. Найбільш розвиненими містами, які мають відповідний туристичний потенціал, який можна використати при організації круїзних подорожей, є Київ, Одеса та Прип'ять [6].

Варто звернути увагу і на те, що вартість загальної кількості послуг, які туристи можуть споживати в цих дестинаціях, являє собою доволі широкий діапазон - від 250 до 2500 гривень - залежно від програми обслуговування та особливостей туристичної дестинації.

Висновки. Підсумовуючи все вище викладене, зробимо наступні висновки та рекомендації.
1. Україна володіє достатньою кількістю природних туристичних ресурсів (річок та морів), які на сьогодні використовуються недостатньо та мають бути задіяні для організації круїзних подорожей.

2. Станом на сьогоднішній день в Україні фрункціонує два круїзних туристичних оператора, які займаються організацією річкових круїзних турів, та одне дочірнє туристичне агентство міжнародної круїзної компанії «MSC Cruises». Органам державної влади необхідно стимулювати появу нових підприємств із організації міжнародних круїзів шляхом сприятливої податкової політики, вигідного лізінгу та відновлення круїзної інсрраструктури.

3. В Україні існує певна кількість портів, котрі можуть використовуватися для організації круїзів, проте нині $€$ незадіяними та достатня кількість наземних туристичних дестинацій, які можуть приваблювати та обслуговувати пасажирів круїзних лайнерів. Рекомендується створювати привабливі для цільової аудиторії круїзні туристичні продукти для стимулювання попиту.

\section{СПИСОК ВИКОРИСТАНИХ ДЖЕРЕЛ:}

1. Романова А.А. П'ять порад, як рятувати український туризм під час пандемії. Новое время. 2020. URL: https://cutt.ly/qhn74W2

2. Круїзна туристична компанія «Червона рута». URL: http://ruta-cruise.com/uk/ (дата звернення: 02.05.2021).

3. Іванов Г.С. Аналіз стану показників розвитку українських портів. Державне управління: удосконалення та розвиток. Дніпро, 2017. № 5. URL: http://www.dy.nayka.com.ua/?op=1\&z=183 (дата звернення: 02.05.2021).

4. Tripadvisor : веб-сайт. URL: https://www.tripadvisor.co.uk/ (дата звернення: 02.05.2021). 
5. Romanova, A. Features and trends of the Chernobyl tourism development. Economic Annals-XXI. 2020. Issue 5-6. P. 134-141. DOI: https://doi.org/10.21003/ea

6. Романова А.А. Дослідження туристичних потоків дестинації: теорія та практика. Вчені записки Таврійського національного університету імені В.І. Вернадського. Серія : Економіка і управління. 2020. № 6. C. 65-69. DOI: https://doi.org/10.32838/2523-4803/70-6-11

\section{REFERENCES:}

1. Romanova A.A. (2020) Piat porad, yak riatuvaty ukrainskyi turyzm pid chas pandemii [Five tips on how to save Ukrainian tourism during a pandemic]. Novoe vremya - New time. Retrited from: https://cutt.ly/qhn74W2

2. Kruizna turystychna kompaniia «Chervona ruta» [Cruise travel company "Chervona Ruta"]. Retrited from: http://ruta-cruise.com/uk/

3. Ivanov H. (2017) Analiz stanu pokaznykiv rozvytku ukrainskykh portiv [Analysis of the state of development indicators of Ukrainian ports]. Derzhavne upravlinnia: udoskonalennia ta rozvytok - Public administration: improvement and development, no. 5. Retrited from: http://www.dy.nayka.com.ua/?op=1\&z=183

4. Tripadvisor. Retrited from: https://www.tripadvisor.co.uk/

5. Romanova A. (2020) Features and trends of the Chernobyl tourism development. Economic Annals-XXI, issue 5-6, pp. 134-141. Retrited from: https://doi.org/10.21003/ea

6. Romanova A. (2020) Doslidzhennia turystychnykh potokiv destynatsii: teoriia ta praktyka [Research of tourist flows of the destination: theory and practice]. Vcheni zapysky Tavriiskoho natsionalnoho universytetu imeni V.I. Vernadskoho. Seriia: Ekonomika i upravlinnia - Scientific notes of Tavriya National University named after VI Vernadsky. Series: Economics and Management, 6, 65-69. Retrited from: https://doi.org/10.32838/2523-4803/70-6-11 